\title{
PERCEPTIONS REGARDING THE CLINICAL ACCOMPANIMENT OF STUDENT NURSES IN THE LIMPOPO PROVINCE
}

\section{Ms Esther M Lekhuleni}

BA Cur, Honours BA Cur, MA Cur: general nurse, midwife, community health nurse, nurse tutor MA Cur student, Department of Advanced Nursing Sciences, Unisa and Senior Lecturer, Department of Nursing, University of the North

\section{Dr Dirk M van der Wal}

BA; BA Cur; Honours BA Cur; MA Cur; D Litt et Phil; general nurse, community health nurse, nurse educator, nurse administrator

Senior Lecturer, Department of Advanced Nursing Sciences, Unisa

\section{Dr Valerie J Ehlers}

B Soc Sc (Nursing); Honours BA (SS) (Psychology); BA Cur; Honours BA Cur; MA Cur; D Litt et Phil; Diploma in Development Studies; general nurse, midwife, community health nurse, psychiatric nurse, nurse educator, nurse administrator

Senior Lecturer, Department of Advanced Nursing Sciences, Unisa

Corresponding author: ehlervj@unisa.ac.za

Keywords: accompaniment; clinical teaching/learning; perceptions/expectations of clinical learning

\section{SUMMARY}

A quantitative, descriptive, cross-sectional survey was carried out in the Limpopo Province to identify the perceptions of student nurses, nurse educators and unit supervisors concerning student nurses' clinical accompaniment in this province. The research objective was to determine whether or not clinical accompaniment of student nurses in the Limpopo Province was perceived to be adequate by the student nurses themselves as well as by the nurse educators and the unit supervisors. The population for this study comprised all second-, third-and fourth-year student nurses, all nurse educators from the university and the colleges, and all unit supervisors from the health institutions within the Limpopo Province of the Republic of South Africa. Simple random sampling was used to ensure that every student nurse from each nursing college had an equal chance of being chosen. No sampling procedures were applied to university student nurses, nurse educators and unit supervisors as these entire small target populations participated in the research. A self-designed questionnaire was used for data collection. The face and content validity of the items were accepted by three experts in the field. The Statistical Package of Social Sciences (SPSS) program was used to analyse data. The research results indicated that student nurses and nurse educators focussed on educational outcomes while unit supervisors focussed on patient care outcomes during clinical accompaniment. Both student nurses and unit supervisors expected nurse educators to accompany student nurses in the clinical settings, but the majority of the nurse educators did not perceive clinical accompaniment to be one of their tasks. Student nurses' clinical accompaniment could be enhanced if nurse educators would be available in the clinical situations and if communication and interpersonal relationships among various categories of nurses could be improved. In-service education could also help to realise this ideal.

\section{OPSOMMING}

'n Kwantitatiewe, beskrywende, deursnitopname is gebruik om die persepsies van verpleegstudente, verpleegopvoedkundiges en eenheidstoesighouers oor verpleegstudente se kliniese begeleiding in the Limpopo Provinsie te identifiseer. Die navorsingsdoelwit was om vas te stel of die kliniese begeleiding van verpleegstudente in die Limpopo Provinsie voldoende was, al dan nie, soos waargeneem deur die studente self, asook deur die 
verpleegopvoedkundiges en eenheidstoesighouers. Die populasie vir die studie het alle tweede-, derde- en vierdejaar verpleegstudente asook alle verpleegopvoedkundiges van die universiteit en die kolleges, en alle eenheidstoesighouers van die onderskeie gesondheidsinrigtings binne die Limpopo Provinsie van die Republiek van Suid-Afrika (RSA) ingesluit. Eenvoudige ewekansige steekproefneming is gebruik ten einde te verseker dat elke verpleegstudent van elke verpleegkollege 'n gelyke kans gehad het om gekies te word. Geen steekproewe is van universiteitstudente, verpleegopvoedkundiges of eenheidstoesighouers geneem nie, aangesien hierdie klein populasies in die geheel aan die studie deelgeneem het. Vraelys wat self ontwerp is, is benut om data in te samel. Die sig- en inhoudsgeldigheid is deur drie deskundiges op dié gebied aanvaar. Die "Statistical Package of Social Sciences (SPSS)" program is gebruik om die data te ontleed. Die navorsingsresultate toon aan dat verpleegstudente en verpleegopvoedkundiges op opvoedkundige uitkomste fokus, terwyl die eenheidstoesighouers op pasiëntsorguitkomste tydens kliniese begeleiding konsentreer. Beide verpleegstudente en eenheidstoesighouers het verwag dat verpleegopvoedkundiges studente in die kliniese situasies sou begelei, maar die meeste verpleegopvoedkundiges het nie kliniese begeleiding as een van hulle pligte beskou nie. Die kliniese begeleiding van verpleegstudente kan bevorder word indien verpleegopvoedkundiges beskikbaar sou wees in die kliniese eenhede en indien kommunikasie asook interpersoonlike verhoudings tussen alle kategorieë verpleegkundiges sou verbeter. Indiensopleiding kan ook help om dié ideaal te verwesenlik.

\section{INTRODUCTION}

This study attempted to describe the perceptions of student nurses, nurse educators and unit supervisors on the accompaniment of student nurses in clinical situations in the Limpopo Province of the Republic of South Africa (RSA). The South African Nursing Council (SANC) asserts that accompaniment of student nurses is indispensable in all teaching situations and that all registered professional nurses and midwives are indispensable in the accompaniment of student nurses in clinical settings (SANC, 1992:7). In the clinical settings student nurses develop from dependency towards independency, and from pedagogy towards andragogy (Dana \& Gwele, 1998:60; Kotze, 1998:4). As student nurses progress towards the final stages of their professional education they should become more confident and less dependent on the nurse educators and supervisors (Windsor, 1987:152). However, the accompaniment of student nurses might be inadequate in some clinical settings in the RSA, hampering the professional development of the student nurses and impeding their abilities to integrate theory and practice and to become analytical critical thinkers who can make independent judgments in clinical settings. Such unsatisfactory clinical accompaniment of student nurses in the RSA has indeed been reported by Mhlongo (1996:29) who maintained that student nurses perceived themselves to be "pairs of hands", that teaching was given low priority and that many clinical learning opportunities were not used - impacting negatively on the professional development of the student nurses.

\section{PROBLEM STATEMENT, PURPOSE AND OBJECTIVES OF THE RESEARCH}

Student nurses' reflective journals portrayed their perceived dissatisfaction with their clinical learning experiences; indicating that neither nurse educators nor unit supervisors provided adequate accompaniment during students' clinical placements in the Limpopo Province (Lekhuleni, 2002:3). Inadequate accompaniment in the clinical settings, would hamper student nurses' professional growth and development, producing inadequately prepared and clinically incompetent newly registered professional nurses to enter the nursing profession with potentially hazardous consequences for the nurses themselves, the nursing profession and their patients/clients. The research problem was to determine whether or not clinical accompaniment of student nurses in the Limpopo Province was perceived to be adequate by the student nurses themselves as well as by the nurse educators and the unit supervisors. Based on this information, recommendations could be made for enhancing student nurses' clinical accompaniment in the Limpopo Province.

The purpose of the research was to identify the percep- 
tions of student nurses, nurse educators and unit supervisors regarding the accompaniment of student nurses in clinical settings in the Limpopo Province.

The objectives of the research were to:

- $\quad$ conduct a literature review in order to clarify concepts pertaining to accompaniment in the clinical situation, namely mentorship, facilitation, preceptorship, supervision and role modelling;

- $\quad$ determine the perceptions of student nurses, nurse educators and unit supervisors regarding the accompaniment of student nurses in clinical settings;

- $\quad$ establish the role of the nurse educators and unit supervisors during the accompaniment of student nurses in clinical settings;

- $\quad$ establish congruence or incongruence of perceptions among student nurses, nurse educators and unit supervisors about the accompaniment of student nurses in clinical settings in the Limpopo Province; and

- $\quad$ obtain input from student nurses, nurse educators and unit supervisors on improvement of accompaniment in clinical settings.

\section{REVIEW OF LITERATURE RELEVANT TO CLINICAL ACCOMPANIMENT}

The review of literature revealed the following significant concepts related to the research topic, accompaniment: facilitation; mentorship; preceptorship; supervision and role modelling which will be discussed in terms of the relevant literature.

\section{Facilitation}

In the study conducted by Chabeli (1999:26) in the RSA, facilitation is defined as a goal directed and dynamic process in which professional nurses and student nurses interact in a clinical learning environment of genuine mutual respect. The characteristics of effective facilitators include the ability to create a climate of trust engendered by appropriate self-disclosure of student nurses and facilitators, with warm, open and honest approaches towards each other. These characteristics should be coupled with dedication, sincerity, enthusiasm, optimism and knowledge about the course and programme requirements of student nurses (Fryer,
1996:69; Musinski, 1999:29; Quinn, 1995:200). It is the role of facilitators to inform and advise student nurses, particularly in relation to course work and assessment, ascribe appropriate independence and autonomy, and encourage critical thinking and enquiry (Quinn, 1995:201). This view of facilitators is supported by MacIntosh (1995:26) who asserts that facilitators should motivate students to be active participants in learning processes rather than passive recipients of information. A study conducted by Schultz (1998:23) in the United States of America (USA) supports the notion that facilitators should advise student nurses systematically and continuously with the intention of assisting them to achieve educational, career and personal goals through utilising a full range of institutional resources.

\section{Mentorship}

The concept "mentor" is derived from the Greek mythology, where Mentor was a trusted friend of Odysseus and tutor of Odysseus's son, Telemachus. The relationship between Mentor and Telemachus has been described as nurturing, educative and protective. Mentor ensured that Telemachus developed personally, socially and professionally (Watson, 1999:255). The foundation of the mentorship programme is the relationship between the experts or accompaniers and the novices or student nurses (Ryan \& Brewer, 1997:22). This notion is supported by Brown (1999:49) who maintains that mentoring is a relationship between two people in which one with greater rank, experience, and/or expertise teaches, counsels, guides and helps the other to develop both professionally and personally.

Gray and Smith (2000:1543) indicate that a good mentor possesses appropriate professional attributes, knowledge, good communication skills and the motivation to teach and support students. Brown (1999:49) reports that helpful mentorship activities, as indicated by mentees, include that mentors should be available, should be good listeners and should provide feedback to mentees.

\section{Preceptorship}

Barret and Myrick (1998:365) maintain that preceptorship might be defined as a one-to-one realitybased clinical experience in which the student nurse is taught directly by a professional nurse. According to 
Usher, Nolan, Reser, Owens and Tollefson (1999:507) preceptors are experienced practitioners who teach, instruct, supervise and serve as role models for student nurses for a set period of time in a formal programme.

According to Jooste and Troskie (1995:12), many preceptors, who participate in the accompaniment of student nurses, are experienced and are not required to rotate shifts. This notion is supported by Bond and Holland (1998:21) who claim that preceptors need to have at least twelve months experience within a specific clinical field.

\section{Supervision}

According to Lewis (1998:40), supervision is a process based on a clinically focussed professional relationship between the practitioner engaged in clinical practice and a clinical supervisor. Supervision allows student nurses to focus on personal and professional strengths and difficulties. Bond and Holland (1998:12) maintain that the role of supervisors is to facilitate the growth of student nurses, both educationally and personally.

\section{Role modelling}

According to Searle and Pera (1995:198), role models hold certain positions in particular social systems, act or behave in manners expected of persons who hold such positions, enact their roles in ways that can be observed and have certain expectations. These authors further cite that role models must have the required knowledge, skills, integrity, personal bearing, neatness, empathy, sympathy and willingness to assist wherever their knowledge and skills are needed, and to be collaborative.

Role models are accountable for what happens in their clinical settings and should be trusted by student nurses because they are professional nurse practitioners. The image projected by role models should at all times be positive and acceptable to student nurses (Searle \& Pera, 1995:253).

\section{Similarities and differences among con- cepts relevant to "accompaniment"}

The similarities among facilitation, mentorship, preceptorship, role modelling and supervision seem to be encouragement of student nurses; providing guidance to and maintaining supportive relationships with student nurses, unit supervisors and nurse educators. Mutual trust and respect underlie all these similarities. The major differences is that mentorship is provided throughout the programme on an advisory, counselling and friendly basis, by professional nurses as well as by peers. On the contrary preceptorship is provided by experienced, competent professional nurses who are unit-based and are not necessarily required to rotate shifts, promoting stability in the student nurses' programme. Preceptors and mentors focus on enhancing the professional development of student nurses, by providing facilitation, mentorship, preceptorship, role modelling and supervision to student nurses in clinical situations.

\section{Accompaniment}

The SANC (1992:6) defines "accompaniment" as the directed assistance and support extended to a student by a registered nurse or a registered midwife with the aim of developing a competent, independent practitioner. During accompaniment student nurses expect to be developed as indicated by the SANC.

\section{Student nurses' expectations of clinical accompaniment}

White and Ewan (1995:20) assert that gaining emancipation through experience has relevance in the clinical learning of student nurses. A study conducted by Kuen (1997:1257) in Hong Kong on the perceptions of effective clinical teaching behaviours in a hospital-based nurse training programme, revealed that student nurses expect nurse educators to provide support and encouragement during accompaniment in clinical settings. The student nurses further expected not to be criticised in front of any other persons nor to be humiliated when corrected. Musinski (1999:24) maintains that the development of student nurses from dependency towards independency could be facilitated when errors are accepted as part of student nurses' learning processes. Student nurses should be able to try out new or different approaches. Should they fail, they should not be humiliated nor embarrassed. Hallet (1997:107) agrees that during accompaniment, nurse educators and unit supervisors provide learning opportunities for student nurses to gain experience, permitting them to progress gradually from 
dependency to independency.

\section{Integration of theory and practice during clinical accompaniment}

Nurse educators are charged with the responsibility of bridging the gap between the worlds of academia and service in clinical settings during accompaniment of student nurses. It may be essential for nurse educators to be involved in the presentation of theory and practice which can facilitate the integration of theory and practice by student nurses during clinical placement and accompaniment. A study conducted by Hicks (1997:8) in the USA, revealed that nurse educators found that methods of patient care management taught to students were not introduced into clinical settings. When student nurses attempted to apply new knowledge about patient care management, their efforts were often misunderstood by unit supervisors, and friction resulted. These findings are supported by Hyrkas (1997:801) who emphasise that skills and knowledge learned in classroom settings make sense when they are applied in clinical settings.

\section{Role of nurse educators and unit super- visors during the clinical accompaniment of student nurses}

According to Cahill (1997:149), nurse educators should have time to develop and maintain their clinical skills and to be involved in clinical teaching for one day per week. Nurse educators should also ensure that learning objectives are met by liaising with unit supervisors supporting both these supervisors and the student nurses. Quinn (1995:187) asserts that unit supervisors should ensure that relevant experiences are provided for student nurses to enable learning outcomes to be achieved.

\section{RESEARCH METHODOLOGY}

A quantitative descriptive cross-sectional survey was used to describe the perceptions of student nurses, nurse educators and unit supervisors of the accompaniment of student nurses in clinical settings in the Limpopo Province. The design was quantitative in that the strategies adopted were specified in advance, in numeric form. The study was also descriptive in that student nurses, nurse educators and unit supervisors described their perceptions of the clinical accompaniment of student nurses. Descriptive statistics were used to describe the data on the perceptions of the participants. The study was cross-sectional in that data were collected simultaneously from second-, thirdand fourth-year student nurses to obtain their perceptions of accompaniment over a three-year period. Burns and Grove (2001:794) define cross-sectional designs as research designs "used to examine groups of subjects in various stages of development simultaneously with the intent of inferring trends over time". According to Polit and Hungler (1997:172), cross-sectional designs are practical, relatively economical and less time-consuming than longitudinal surveys. The purpose of using a cross- sectional design comprising second-, third- and fourth-year students was to obtain the general impressions of these three groups of students.

\section{Population and sampling methods}

First-year student nurses were excluded from the sample because data collection was done during March and April 2001 when the first-year student nurses were still novices in the clinical areas. The population for this study comprised all second-, third- and fourth-year student nurses, all nurse educators from the university and colleges, and all unit supervisors from the health institutions within the Limpopo Province of the RSA. Simple random sampling was used to ensure that every student nurse from each nursing college had an equal chance of being chosen. No sampling procedures were applied to university student nurses, nurse educators and unit supervisors as these small target populations participated in the research.

\section{Data collection instrument}

A self-designed questionnaire was used for data collection. After conducting a literature review, a questionnaire was designed with the help of two nurse researchers and a statistician. The questionnaire consisted of seven sections:

- $\quad$ Section A: Five questions related to the biographical data

- $\quad$ Section B: 18 questions related to the perceptions of the participants with regard to the clinical accompaniment of student nurses

- Section C: 12 questions related to the perceptions of the participants during the actual 
clinical accompaniment of student nurses

- Section D: 11 questions related to the role of student nurses, nurse educators and unit supervisors with regard to their teaching/learning role during clinical accompaniment

- $\quad$ Section E: 55 questions related to the perceptions of the participants with regard to expectations of student nurses in clinical situations

- $\quad$ Section F: Five questions related to perceptions concerning the integration of theory and practice the during clinical accompaniment of student nurses

- $\quad$ Section G: Open-ended questions related to the perceptions of student nurses, nurse educators and unit supervisors with regard to aspects of clinical accompaniment.

\section{Ethical considerations}

Permission to conduct the survey was obtained from the Limpopo Province's Department of Health and Welfare, as well as from health care institutions and nursing colleges which participated in the research. $A$ letter, accompanying each questionnaire, explained the purpose of the research and requested each participant to complete the questionnaire voluntarily and anonymously. No participant received any remuneration whatsoever and there was no discrimination against persons who refused to participate, or who refused to answer specific questions. The completed questionnaires were locked up by the researcher and only the researcher and the statistician had access to these questionnaires. The participants were informed that their names should not appear anywhere on the questionnaires in order to ensure anonymity. Confidentiality was maintained because the participants were ensured that the data from the completed questionnaires would be analysed and published but that no individual participant nor any participating institution would be identified in such a report. Participants could obtain copies of this report from the researcher should they wish to do so.

\section{ANALYSIS AND INTERPRETATION OF THE RESEARCH DATA}

Data obtained from the closed-ended questions in the first six sections of the questionnaire were analysed by a statistician using the Statistical Package for Social Sciences (SPSS) program. Chi-Squares were used to compare differences in the perceptions of the three groups of participants, namely student nurses, nurse educators and unit supervisors. The responses provided to the open-ended questions were grouped and frequencies were calculated for specific groups. Tables were used for data presentation. Knapp (1998:258) maintains that tables are generally more useful for summarising data, as they can be easily understood and interpreted by readers. Bar and pie diagrams were used specifically to illustrate items where the three groups had incongruence of perceptions.

\section{RESEARCH RESULTS}

The research results are presented according to the sections of the questionnaire in an attempt to provide answers to the research question, namely: "What are the perceptions of student nurses, nurse educators and unit supervisors regarding the accompaniment of student nurses in clinical settings?"

\section{Biographic data}

More than half $(62.4 \%)$ of the student nurses were 25 years old or younger while only one nurse educator was younger than 41 , and $77.7 \%$ were older than 46 years of age. On the other hand only $17.1 \%$ of the unit supervisors were older than 45 years of age. This implies that the majority of nurse educators were at least 21 years older than the majority of the student nurses which could imply that a generation gap existed between the nurse educators and student nurses.

Out of the 116 students that participated in the survey $34(29.3 \%)$ were second-, 38 (32.8\%), third- and 44 (37.9\%) fourth-year student nurses. All these students followed the R425 comprehensive four-year programme leading to registration as a nurse (general, community, psychiatric) and midwife (SANC, 1985), but $88.9 \%$ of the nurse educators and $68.8 \%$ of the unit supervisors completed the previous programme (R879) leading to registration as a general nurse only. Thus the majority of the nurse educators and unit supervisors did not follow the same course as the student nurses, and might thus have been unsure about the expectations of the $\mathrm{R} 425$ programme. 


\section{Perceived accompaniment in specific clinical units}

Although $24,7 \%$ of the student nurses were reportedly accompanied mostly in medical units, $40.0 \%$ of the nurse educators indicated that they accompanied student nurses mostly in clinics, and $30,8 \%$ of unit supervisors indicated that they accompanied student nurses mostly in psychiatric units. This could imply that the accompaniment of student nurses might be perceived differently by the students themselves, and the nurse educators and/or unit supervisors. These findings support those of Khoza (1996:224) concerning inadequacies in the implementation of the clinical curriculum in the Limpopo Province.

\section{Perceptions of clinical accompaniment}

The perceptions of the three groups of participants were overwhelming positive (with percentages ranging from $72 \%$ to $100 \%$ ) with regard to questions addressing the motivation of student nurses to develop from dependence towards independence, to cope with unfamiliar situations, to think rationally, to achieve new insights in clinical situations, to encourage an atmosphere of trust in the clinical situation and to maintain mutual respect among the three groups. Unexpectedly student nurses (93\%), nurse educators (95\%) and unit supervisors $(97 \%)$ agreed that clinical learning opportunities were created which enhanced students' development towards independence.

Discrepancies among the three groups of participants' perceptions indicated that

- only $52 \%$ of the student nurses perceived that they were receiving adequate support in clinical situations, while $89 \%$ of the nurse educators and $88 \%$ of the unit supervisors perceived themselves to be providing adequate clinical support to student nurses;

- $\quad$ although $79 \%$ of the student nurses always performed psychomotor skills in the clinical situation, $67 \%$ of the nurse educators and $82 \%$ of the unit supervisors conceded that they always supervised psychomotor skills during clinical accompaniment; and

- $\quad$ as many as $63 \%$ of the student nurses indicated that they seldomly demonstrated affective skills in the clinical settings, but only $22 \%$ of the nurse educators and $47 \%$ of the unit supervisors agreed that they seldomly supervised the implementation of affective skills during clinical accompaniment.

\section{Perceptions with regard to actual clinical accompaniment}

More than $50 \%$ of the participants agreed that the

Table 1: Clinical accompaniment as perceived by student nurses, nurse educators and unit supervisors in specific clinical units

\begin{tabular}{|l|l|l|l|l|l|l|}
\hline \multirow{2}{*}{ CLINICAL AREA } & \multicolumn{2}{l}{$\begin{array}{l}\text { STUDENT NURSES } \\
(\mathbf{n = 1 0 5})\end{array}$} & \multicolumn{2}{l|}{$\begin{array}{l}\text { EDUCATORS } \\
(\mathbf{n}=\mathbf{1 0})\end{array}$} & \multicolumn{2}{l|}{$\begin{array}{l}\text { SUPERVISORS } \\
(\mathbf{n}=\mathbf{2 6})\end{array}$} \\
\cline { 2 - 8 } & $\mathbf{f}$ & $\%$ & $\mathrm{~F}$ & $\%$ & $\mathbf{f}$ & $\%$ \\
\hline Medical & 26 & 24,7 & - & - & 3 & 11,5 \\
\hline Clinics & 22 & 21,0 & 4 & 40,0 & 6 & 23,2 \\
\hline Psychiatry & 17 & 16,2 & 3 & 30,0 & 8 & 30,8 \\
\hline Midwifery & 8 & 7,6 & 3 & 30,0 & 5 & 19,3 \\
\hline Surgical & 7 & 6,7 & - & - & 1 & 3,8 \\
\hline Paediatric & 7 & 6,7 & - & - & - & - \\
\hline Orthopaedic & 6 & 5,7 & - & - & 1 & 3,8 \\
\hline Gynaecology & 5 & 4,8 & - & - & - & - \\
\hline Casualty & 4 & 3,8 & - & - & 1 & 3,8 \\
\hline Outpatients & 3 & 2,8 & - & - & 1 & 3,8 \\
\hline Operating room & - & - & - & - & - & - \\
\hline TOTAL: & $\mathbf{1 0 5}$ & $\mathbf{1 0 0}$ & $\mathbf{1 0}$ & $\mathbf{1 0 0}$ & $\mathbf{2 6}$ & $\mathbf{1 0 0}$ \\
\hline
\end{tabular}


students exercised autonomy, used teachable moments, minimised risk-taking and identified learning needs during accompaniment in clinical settings. The fact that minimised risk-taking was perceived by $87 \%$ of the student nurses, $83 \%$ of the nurse educators and $85 \%$ of the unit supervisors, might indicate that risk-taking was discouraged in these clinical situations, which could impact negatively on the students' development of their critical thinking skills.

There appeared to be incongruence in terms of students' help in coping with a unit's workload. The majority of the student nurses (83\%) reportedly perceived the clinical staff to regard the students as "just some help with the workload", whilst only a minority of nurse educators (11\%) and unit supervisors (17\%) actually portrayed this view. Possibly the nurse educators and unit supervisors perceived the student nurses to be learning while performing patient care tasks while the students perceived themselves to be "working". Similar disagreements occurred with regard to the perception that the majority (90\%) of the student nurses perceived themselves to be controlled in the clinical situation while only $11 \%$ of the nurse educators and $40 \%$ of the unit supervisors perceived themselves to be controlling student nurses during clinical accompaniment. This apparent discrepancy could indicate that the students' perceived "accompaniment" in terms of the nurse educators' and unit supervisors' actions to be "control", rather than "accompaniment". Thus there appeared to be a need for enhancing the climate of trust between student nurses, nurse educators and unit supervisors in the Limpop Province, as advocated by a number of authors (Fryer, 1996:69; Musinski, 1999:29; Quinn, 1995:200).

\section{Perceptions with regard to teaching and learning in the clinical situation}

More than $50 \%$ of the participants agreed with the ten items in this section of the questionnaire. Most of the student nurses (93\%), nurse educators (94\%) and unit supervisors (91\%) agreed that learning needs were identified during clinical accompaniment. Similarly, almost all the student nurses (93\%), nurse educators (94\%) and unit supervisors (97\%) agreed that theory and practice were linked during accompaniment in the clinical settings. Incongruence occurred only in one item regarding availability in clinical settings, where $39 \%$ of the student nurses indicated that the nurse educators and unit supervisors were sometimes not available when needed by the student nurses; $56 \%$ of the nurse educators and $57 \%$ of the unit supervisors agreed with the students' perception, implying that less than $50 \%$ of both the nurse educators and unit supervisors perceived themselves to be available to the student nurses in the clinical situations in the Limpopo Province.

\section{Perceptions concerning student nurses' expectations in clinical settings}

No major discrepancies were identified among the three groups of responses to the nine items comprising this section of the questionnaire (as reflected in Table 2), indicating that the student nurses, nurse educators and unit supervisors agreed about the student nurses' expectations in the clinical settings in the Limpopo Province.

\section{Perceptions concerning the integration of theory and practice during the accompa- niment of student nurses in the clinical settings}

The three groups of participants provided incongruent responses for five items, namely

- $50 \%$ of the student nurses, $61 \%$ of the nurse educators and $47 \%$ of the unit supervisors agreed that friction arose in clinical settings when student nurses attempted to apply new knowledge to patient care in clinical situations

- $31 \%$ of the student nurses, $28 \%$ of the nurse educators and $50 \%$ of the unit supervisors perceived student nurses to lack a well-developed theoretical base for integrating theory and practice

- $26 \%$ of the student nurses, $67 \%$ of the nurse educators and $64 \%$ of the unit supervisors perceived student nurses to lack competence in the application of theory to practice

- $\quad 85 \%$ of the student nurses, $78 \%$ of nurse educators and $73 \%$ of the unit supervisors reportedly perceived student nurses to be competent to apply theory to practice in clinical settings (supporting the previous finding)

- $52 \%$ of the student nurses, $56 \%$ of the nurse educators and $35 \%$ of the unit supervisors 
agreed that emphasis was placed on skills rather on caring during clinical assignments.

\section{Perceptions concerning specific aspects of the accompaniment of student nurses in clinical settings in the Limpopo Prov- ince}

Open-ended questions allowed participants opportunities to respond in their own words. These responses were coded into similar categories. The major finding revealed that the accompaniment of student nurses in clinical settings by nurse educators and unit supervisors appeared to be inadequate.

\section{Availability of accompanists}

Student nurses $(57.8 \%)$ indicated that the availability of accompanists is very important, but only $17.5 \%$ of the nurse educators and $8.6 \%$ of the unit supervisors considered their availability to be an important aspect of accompaniment.

More than half $(57.8 \%)$ of the student nurses indicated that accompaniment should be done by nurse educators, but only $11.1 \%$ of the nurse educators held this view compared to $35.5 \%$ of the unit supervisors who expected nurse educators to accompany student nurses in the clinical settings. Unexpectedly no student nurse expected unit supervisors to accompany students in the clinical settings, while $11.1 \%$ of the nurse educators and $35.3 \%$ of the unit supervisors expected this to be the case. No reasons could be deduced from the students' answers as to why they did not expect unit supervisors to accompany them in the clinical settings.

In contrast to the expected accompaniment (discussed in the previous paragraph) students' actual accompaniment in the clinical settings was reportedly done by nurse educators according to $56.7 \%$ of the student nurses, $61.1 \%$ of the nurse educators and $55.9 \%$ of the unit supervisors. Although only $11.1 \%$ of the nurse educators reportedly regarded clinical accompaniment of student nurses to be an expectation of their role, $61.1 \%$ of the nurse educators reportedly succeeded in accompanying students in the clinical settings of the Limpopo Province.

Table 2: Perceptions concerning student nurses' expectations in clinical settings

\begin{tabular}{|c|c|c|c|c|c|c|c|c|c|c|c|c|}
\hline \multirow{3}{*}{$\begin{array}{l}\text { ITEMS FROM THE } \\
\text { QUESTIONNAIRE } \\
\text { Student nurses expect to be }\end{array}$} & \multicolumn{4}{|c|}{$\begin{array}{l}\text { STUDENT NURSES } \\
(n=116)\end{array}$} & \multicolumn{4}{|c|}{$\begin{array}{l}\text { NURSE EDUCATORS } \\
(n=18)\end{array}$} & \multicolumn{4}{|c|}{$\begin{array}{l}\text { UNIT SUPERVISORS } \\
(n=35)\end{array}$} \\
\hline & \multicolumn{2}{|c|}{ Agree } & \multicolumn{2}{|c|}{ Disagree } & \multicolumn{2}{|c|}{ Agree } & \multicolumn{2}{|c|}{ Disagree } & \multicolumn{2}{|c|}{ Agree } & \multicolumn{2}{|c|}{ Disagree } \\
\hline & $f$ & $\%$ & $\mathbf{f}$ & $\%$ & $f$ & $\%$ & $f$ & $\%$ & $f$ & $\%$ & $f$ & $\%$ \\
\hline $\begin{array}{l}\text { emancipated through clinical } \\
\text { experience }\end{array}$ & 110 & 95 & 6 & 5 & 14 & 82 & 3 & 18 & 33 & 100 & - & - \\
\hline supported in clinical settings & 113 & 96 & 5 & 4 & 18 & 100 & - & - & 35 & 100 & - & - \\
\hline encouraged in clinical settings & 115 & 97 & 3 & 3 & 18 & 100 & - & - & 34 & 97 & 1 & 3 \\
\hline criticised in clinical settings & 47 & 40 & 71 & 60 & 7 & 39 & 11 & 61 & 15 & 43 & 20 & 57 \\
\hline corrected in clinical settings & 116 & 99 & 1 & 1 & 18 & 100 & - & - & 31 & 89 & 4 & 11 \\
\hline guided in clinical settings & 116 & 98 & 2 & 2 & 16 & 89 & 2 & 11 & 30 & 88 & 4 & 12 \\
\hline $\begin{array}{l}\text { involved in clinical decision- } \\
\text { making }\end{array}$ & 115 & 97 & 3 & 3 & 17 & 94 & 1 & 6 & 32 & 91 & 3 & 9 \\
\hline assisted to identify their limitations & 111 & 94 & 7 & 6 & 17 & 94 & 1 & 6 & 30 & 86 & 5 & 14 \\
\hline assisted to identify their strengths & 106 & 90 & 12 & 10 & 17 & 94 & 1 & 6 & 31 & 89 & 4 & 11 \\
\hline
\end{tabular}

In each category "n" indicates the total number of participants. However, all participants did not answer each question. Consequently "n" could be fewer for any item than that indicated for the specific category of participants. Percentages were calculated on the number of responses to the item and not on "n". 
Role of accompanists in the clinical settings

Surprisingly only $36.6 \%$ of the student nurses perceived the demonstration of procedures to be the most important aspect of clinical accompaniment while none of the nurse educators and none of the unit supervisors perceived this to be the case. The nurse educators $(44.4 \%)$ and the student nurses $(33.0 \%)$ agreed that evaluation of student nurses was an important function of the clinical accompanists but only $20.0 \%$ of the unit supervisors held this view.

\section{Potential improvement of the accompani- ment of student nurses in clinical settings}

The highest responses to this open-ended question indicated that student nurses' accompaniment in the clinical settings would be improved if nurse educators would be available $(57.7 \%$ of the student nurses and $44.4 \%$ of the unit supervisors but only $5.6 \%$ of the nurse educators). The nurse educators (22.2\%) and the unit supervisors (22.2\%) agreed that in-service education and improved interpersonal relations $(22.2 \%$ nurse educators and $18.6 \%$ unit supervisors) could enhance student nurses' clinical accompaniment. While $16.7 \%$ of the nurse educators indicated that this goal could be achieved by appointing clinical preceptors, only $1.7 \%$ of the students and none of the unit supervisors mentioned this aspect.

\section{Student nurses' roles during clinical ac- companiment}

A general trend which appeared from analysing the openended responses, summarised in Table 4, indicated that student nurses (51\%) should be responsible for their own learning while only $11.8 \%$ of the nurse educators and $11.3 \%$ of the unit supervisors portrayed this view. Although $58.8 \%$ of the nurse educators and $45.7 \%$ of the unit supervisors considered students' participation in the clinical accompaniment process to be essential, only $20.0 \%$ of the student nurses agreed.

\section{CONCLUSIONS}

An analysis of the data obtained from the completed questionnaires by student nurses, nurse educators and unit supervisors indicated that student nurses and nurse educators perceived accompaniment to focus on educational outcomes, but unit supervisors focussed on patient care outcomes. Although most clinical accompaniment was done by nurse educators who claimed to support students, their students perceived the nurse educators to demonstrate procedures and evaluate students in the clinical settings.

\section{Perceptions of clinical accompaniment}

The use of clinical learning objectives and exploration of learning by student nurses was perceived to be the

Table 3: $\quad$ The role of the accompanists in clinical settings

\begin{tabular}{|l|l|l|l|l|l|l|}
\hline $\begin{array}{l}\text { SPECIFIC FUNCTIONS OF THE } \\
\text { ROLE OF ACCOMPANISTS }\end{array}$ & $\begin{array}{l}\text { STUDENT } \\
\text { NURSES } \\
(\mathrm{n}=\mathbf{1 1 2})\end{array}$ & $\begin{array}{l}\text { NURSE } \\
\text { EDUCATORS } \\
(\mathbf{n = 1 8})\end{array}$ & \multicolumn{3}{l|}{$\begin{array}{l}\text { UNIT } \\
\text { SUPERVISORS } \\
(\mathbf{n = 3 5})\end{array}$} \\
\cline { 2 - 8 } & $\mathbf{f}$ & $\%$ & $\mathbf{f}$ & $\%$ & $\mathbf{f}$ & $\%$ \\
\hline Demonstrating procedures & 41 & 36,6 & - & - & - & - \\
\hline Evaluating student nurses & 37 & 33,0 & 8 & 44,4 & 7 & 20,0 \\
\hline Teaching student nurses & 17 & 15,2 & 3 & 16,7 & 13 & 37,1 \\
\hline Correlating theory and practice & 17 & 15,2 & 4 & 22,2 & 8 & 22,9 \\
\hline Supporting student nurses & - & - & 3 & 16,7 & 3 & 8,6 \\
\hline Creating learning milieu & - & - & - & - & 4 & 11,4 \\
\hline TOTAL: & $\mathbf{1 1 2}$ & $\mathbf{1 0 0}$ & $\mathbf{1 8}$ & $\mathbf{1 0 0}$ & $\mathbf{3 5}$ & $\mathbf{1 0 0}$ \\
\hline
\end{tabular}

In each category "n" indicates the total number of participants. However, all participants did not answer each question. Consequently "n" could be fewer for any item than that indicated for the specific category of participants. Percentages were calculated on the number of responses to the item and not on " $n$ ". 
Table 4: Student nurses' roles during clinical accompaniment

\begin{tabular}{|c|c|c|c|c|c|c|}
\hline \multirow[t]{2}{*}{ ROLE OF STUDENT NURSES } & \multicolumn{2}{|c|}{$\begin{array}{l}\text { STUDENT } \\
\text { NURSES } \\
(n=100)\end{array}$} & \multicolumn{2}{|c|}{$\begin{array}{l}\text { NURSE } \\
\text { EDUCATORS } \\
(n=18)\end{array}$} & \multicolumn{2}{|c|}{$\begin{array}{l}\text { UNIT } \\
\text { SUPERVISORS } \\
(n=35)\end{array}$} \\
\hline & $f$ & $\%$ & $f$ & $\%$ & $f$ & $\%$ \\
\hline Responsible for learning & 51 & 51,0 & 2 & 11,8 & 4 & 11,3 \\
\hline Participation & 20 & 20,0 & 10 & 58,8 & 16 & 45,7 \\
\hline Integration of theory and practice & 13 & 13,0 & 1 & 5,9 & 8 & 22,9 \\
\hline $\begin{array}{l}\text { Movement from dependency to } \\
\text { independency }\end{array}$ & 10 & 10,0 & - & - & 3 & 8,6 \\
\hline Readiness to learn & 4 & 4,0 & 1 & 5,9 & 3 & 8,6 \\
\hline Commitment to practice & 2 & 2,0 & 3 & 17,6 & 1 & 2,9 \\
\hline TOTAL: & 100 & 100 & 17 & 100 & 35 & 100 \\
\hline
\end{tabular}

In each category "n" indicates the total number of respondents. However, all participants did not answer each question. Consequently "n" could be fewer for any item than that indicated for the specific category of participants. Percentages were calculated on the number of responses to the item and not on "n".

core emphasis of accompaniment in clinical settings. Clinical accompaniment was perceived as being the availability of nurse educators in clinical settings (57.7\%); as providing support to student nurses by nurse educators (35.3\%); while unit supervisors $(60 \%)$ regarded accompaniment to comprise the follow-up of students by nurse educators in the clinical settings.

\section{Role of the nurse educators and unit su- pervisors during clinical accompaniment}

Nurse educators and unit supervisors indicated their teaching role as being the correlation of theory and practice, the evaluation of student nurses and assisting student nurses to develop competencies. Student nurses perceived their learning role in clinical settings as being the development of competency, linking theory with practice and using learning resources available in clinical settings.

\section{The improvement of accompaniment in clinical settings}

Clinical accompaniment of student nurses in the Limpopo Province could be improved by the enhanced availability of nurse educators in the clinical settings, according to the student nurses and the unit supervisors. The nurse educators maintained that this could be accomplished through improved communication and interpersonal relationships among nurse educators, unit supervisors and student nurses. Both nurse educators and unit supervisors indicated that in-service education could enhance students' clinical accompaniment.

\section{Similarities/differences in the perceptions of student nurses, nurse educators and unit supervisors}

The study revealed that student nurses and unit supervisors perceived that nurse educators should accompany student nurses in clinical settings, but nurse educators viewed accompaniment to be a collaborative activity with unit supervisors and other health team members to facilitate the development of student nurses towards professional maturity.

\section{LIMITATIONS OF THE RESEARCH PROJECT}

Only a limited number of responses from nurse educators were received despite repeated follow-up attempts. Generalising the findings of this research pertaining to all three groups (student nurses, unit supervisors and nurse educators), and particularly the research findings relevant to nurse educators, should thus be done cautiously. The research was only conducted within the Limpopo Province, and research results may thus 
not necessarily be generalisable to other provinces of the RSA.

\section{RECOMMENDATIONS FOR IMPROVING STUDENT NURSES' CLINICAL ACCOM- PANIMENT IN THE LIMPOPO PROVINCE}

Workshops should be organised where student nurses, nurse educators and unit supervisors could clarify their expectations, as well as their evaluations, of student nurses' clinical accompaniment in the Limpopo Province. These research results could be used as points of departure for such discussions.

Nurse educators should move from the demonstration of procedures and evaluation of student nurses' skills during students' clinical accompaniment towards comprehensive patient care, including affective aspects. Student nurses should be encouraged to keep their reflective journals concerning their clinical learning experiences up to date and to submit these at the end of each month to be perused by nurse educators. Recurrent weaknesses and strengths should be identified by nurse educators and addressed together with the student nurses and the unit supervisors.

The employment of preceptors by nursing education institutions for the possible improvement of accompaniment of student nurses in clinical settings should be further pursued. Alternatively the possibility of appointing more nurse educators so that they can teach both theory and practice should be investigated.

The Limpopo Province needs to motivate professional nurses, younger than 35 years of age, to consider becoming nurse educators as the majority of nurse educators would reach retirement age within the next decade.

\section{FINAL COMMENT}

"Change in the future relates to where students will have their practice expertise and the knowledge and competence they will need to practice in the future. Constancy in the future rests with the extent of the preparation to provide humanistic nursing care to clients in order to facilitate optimum health. For the educators, the source of constancy remains in the purposes for the use of the clinical field in preparation of tomorrow's nurses, learning how to learn, dealing with ambiguity, thinking like professionals and developing personal causation" (Reilly \& Oermann, 1999:489).

\section{BIBLIOGRAPHY}

BARRETT, C \& MYRICK, F 1998: Job satisfaction in preceptorship and its effects on the clinical performance of the preceptee. Journal of Advanced Nursing, 27(2):364-371.

BOND, M \& HOLLAND, S 1998: Skills of clinical supervision for nurses: A practical guide for clinical supervisors and managers. London: Open University Press.

BROWN, HN 1999: Mentoring new faculty. Nurse Educator, 24(1):48-51.

BURNS, N \& GROVE, SK 2001: The practice of nursing research: Conduct, critique and utilization. Philadelphia: WB Saunders.

CAHILL, HA 1997: What should nurse teachers be doing? A preliminary study. Journal of Advanced Nursing, 26(1):146-153. CHABELI, M 1999: Student nurses' learning needs and expectations in the clinical learning units. Curationis, 22(4):24-28.

DANA, N \& GWELE, NS 1998: Perceptions of student nurses of their personal and academic development during placement in the community as a clinical learning environment. Curationis, 21(1):58-63.

FRYER, M 1996: Creative teaching and learning. London: Paul Chapman.

GRAY, MA \& SMITH, LN 2000: The qualities of an effective mentor from the student nurses' perspective: Findings from a longitudinal qualitative study. Journal of Advanced Nursing, 32(6):15421549.

HALLET, CE 1997: Learning through reflection in the community: The relevance of Schon's theories of coaching to nursing education. International Journal of Nursing, 34(2):103-110. HICKS, BC 1997: Integration of clinical and academic nursing at the hospital clinical unit level. Journal of Nursing Education, 16(4):6-9.

HYRKAS, K 1997: Can action research be applied in developing clinical teaching? Journal of Advanced Nursing, 25(2):801808.

JOOSTE, K \& TROSKIE, R 1995: Staff development. Cape Town: Southern Books.

KHOZA, LB 1996: The competency of newly qualified nurses as viewed by senior professional nurses. Pretoria: University of South Africa. (D Litt et Phil thesis).

KNAPP, TR 1988: Qualitative nursing research. London: Sage. KOTZE, J 1989: An anthropological nursing science: Nursing accompaniment theory. Health SA Gesondheid, 3(2):3-4.

KUEN, M 1997: Perceptions of effective clinical teaching behaviours in a hospital-based nurse training programme. Journal 
of Advanced Nursing, 26(6):1252-1261.

LEWIS, D 1998: Clinical supervision for nurse lecturers. Nursing

Standards, 12(29):40-43.

LEKHULENI, EM 2002: The perceptions/views of nursing students, nurse educators and unit supervisors on accompaniment of nursing students in the clinical setting. Pretoria: University of South Africa. (MA Cur dissertation).

MACINTOSH, J 1995: Fashioning facilitators nursing education for primary health care. Nurse Educator, 20(3):25-27.

MHLONGO, CS 1996: The role of unit sisters in teaching student nurses in Kwazulu hospitals. Curationis, 19(3):28-31.

MUSINSKI, B 1999: The educator as facilitator: A new kind of leadership. Nursing Forum, 34(1):23-29.

POLIT, DF \& HUNGLER, BP 1997: Essentials of nursing research: Methods, appraisal and utilization. Philadelphia: JB Lippincott.

QUINN, FM 1995: The principles and practice of nurse education. London: Chapman \& Hall.

REILLY, DE \& OERMANN, MH 1999: Clinical teaching in nursing education; $2^{\text {nd }}$ edition. Sudbury: Jones \& Bartlett.

RYAN, D \& BREWER, K 1997: Mentorship and professional role development in undergraduate nursing education. Nurse Educator, 22(6):20-24.

SANC - See South African Nursing Council.

SCHULTZ, ED 1998: Academic advising from a nursing theory perspective. Nurse Educator, 23(2):22-23.

SEARLE, C \& PERA, SA 1995: Professional practice: A South African perspective. Durban: Butterworths.

SOUTHAFRICAN NURSING COUNCIL 1985: Minimum requirements for the education and guide concerning teaching of students in the programme leading to registration as a nurse (general, psychiatric and community) and midwife. Regulation 425, as amended. Pretoria: SANC.

SOUTH AFRICAN NURSING COUNCIL 1992: The philosophy and policy of the South African Nursing Council with regard to professional nursing education. Pretoria: SANC.

USHER, K; NOLAN, C; RESER, P; OWENS, J \& TOLLEFSON, J 1999: An exploration of the preceptor role: Receptors' perceptions of benefits, rewards, supports and commitments to the preceptor role. Journal of Advanced Nursing, 29(2):506-514.

WATSON, NA 1999: Mentoring today: The students' view, an investigative case study of pre-registration nursing students' experience and perceptions of mentoring in one theory/practice module of the common foundation programme on a project 2000 course. Journal of Advanced Nursing, 29(1):254-262. WHITE, R \& EWAN, C 1995: Clinical teaching in nursing. London: Chapman \& Hall.

WINDSOR, A 1987: Nursing students' perceptions of clinical experiences. Journal of Nursing Education, 26(4):150-154. 